\title{
Minutes of the $137^{\text {th }}$ Annual Business Meeting of the Ottawa Field-Naturalists' Club March 21, 2016
}

Place and time: $\quad$ Fletcher Wildlife Garden, Ottawa, Ontario, 7:00 pm

Chairperson: $\quad$ Fenja Brodo, President of the OFNC

Over 20 attendees spent the first half-hour reviewing the minutes of the previous ABM, the financial statements, the OFNC committees' annual reports for 2014-2015 and the newly updated Terms of Reference for each committee. The meeting was called to order at 7:30 pm.

\section{Minutes of the Previous Annual Business Meeting}

It was moved by Annie Bélair and seconded by Diane Lepage that the minutes of the $136^{\text {th }}$ Annual Business Meeting be accepted as distributed.

Carried

\section{Business Arising from the Minutes}

Ann gave an update on the review of the constitution and bylaws of the club. (See item 8 in the minutes of the 2015 ABM.)

The club started updating its constitution and bylaws because the Ontario government had announced that it would amend the Ontario Not-for-Profit Corporations Act. However, the act has not been proclaimed yet and the accompanying regulations have not been written. Ann explained that her committee has decided to continue to update the By-Laws regardless of the legal requirement to do so.

\section{Communications Relating to the Annual Business Meeting \\ Nil.}

\section{Treasurer's Report by Ken Young}

Copies of the financial statements, a summary table of the financial statements, and the 2016 budget were made available to all attendees.

Ken reminded everyone that the fiscal year runs from October 1 to September 30.

He then presented the financial statements, which were reviewed by the accounting firm of Welch LLP. He said that the club's financial position is pretty good, and explained that the major sources of revenue are membership fees, donations and bequests, and The Canadian Field-Naturalist, which, except for bequests, have all increased in 2015.

Ken pointed out that the entirety of the Czasak bequest is now showing in the financial statements; the net disbursements to the club from the entire estate totals $\$ 1,235,226$.

The increase in revenue in the last two years led to some larger expenses in 2014-2015 such as: a donation of $\$ 200,000$ to the Nature Conservancy of Canada to- wards the purchase of land near Westmeath (the Gervais Caves), the creation of the OFNC Research Grants ( $\$ 15,000$ yearly), a donation of $\$ 5000$ to the Mississippi Valley Field Naturalists to help cover the cost of the appeal to the Ontario Municipal Board to stop a planned housing development that would destroy a portion of the Burnt Lands Alvar, and a donation of $\$ 4500$ to the Innis Point Bird Observatory to help them hire a bander-in-charge for the 2016 Spring Migration Monitoring Program.

For the 2015-2016 fiscal year, the OFNC is considering donating money to the MacSkimming and Bill Mason Outdoor Education Centres to help pay for buses and some equipment, is working with a contractor to modernize the website, will offer the research grants again, and has renovated the Fletcher Wildlife Garden interpretation centre.

In closing, Ken thanked Frank Pope, past treasurer, and Ann MacKenzie for their continuing help.

Motion: It was moved by Ken Young and seconded by Gord Robertson that the financial statements be accepted as a fair representation of the financial position of the Club as of September 30, 2015.

\section{Nomination of the Accounting Firm}

Carried

Moved by Ken Young and seconded by Ann MacKenzie that the accounting firm of Welch LLP be contracted to conduct a review of the OFNC's accounts for the fiscal year ending September 30, 2016.

Carried

\section{Committee Reports}

The annual committee reports serve as a record of what the OFNC does throughout the year. A copy of the reports was distributed to attendees at the beginning of the meeting.

Moved by Annie Bélair and seconded by Jakob Mueller that the reports be accepted as distributed.

Carried

\section{Updated Terms of Reference of OFNC Committees}

Each OFNC committee updated its Terms of Reference in 2015. These Terms of Reference were then for- 
matted by Louis L'Arrivée and published on the OFNC website. Fenja pointed out that if a committee wishes to modify its Terms of Reference, it simply needs to bring it up at a board of directors' meeting.

\section{Report of the Nominating Committee Ann MacKenzie}

Relevant Excerpts from the OFNC Constitution (revised February 2000)

Article 8 - "The Council shall consist of the officers of the Club and up to eighteen additional members, all members of the Club."

Article 12 - "The officers of the Club and other members of the Council shall be elected annually at the Annual Business Meeting. The nomination of sufficient persons for election to the various offices and membership of the Council shall be the responsibility of the Nominating Committee, which shall act in the manner prescribed in the By-Laws.

The Council shall, at the earliest possible date, appoint chairs and members of Standing and ad hoc committees and Editor and Business Managers, as required for club publications."

$\begin{array}{ll}\text { NominATEd OfFICERS } & \text { OfFICIAL DUtY } \\ \text { Fenja Brodo } & \text { President } \\ \text { Diane Lepage } & \text { 1st Vice-President } \\ \text { vacant } & \text { 2nd Vice-President } \\ \text { Lynn Ovenden } & \text { Recording Secretary } \\ \text { Ken Young } & \text { Treasurer }\end{array}$

Nominated Other Members (in alphabetical order) Annie Bélair Ann MacKenzie

Carolyn Callaghan Jakob Mueller

Owen Clarkin Rémy Poulin

Barry Cottam Gordon Robertson

Edward Farnworth Jeff Saarela

Diane Kitching Henry Steger

Alex MacDonald Eleanor Zurbrigg

Motion: Moved by Ann MacKenzie and seconded by Ernie Brodo that this slate of nominees be accepted as members of the Board of Directors of the OFNC for 2016.

Carried
Fenja thanked Barbara Chouinard, Karen McLachlan Hamilton, Louis L'Arrivée and Julia Cipriani who will not be returning to the Board. She thanked Henry Steger and Eleanor Zurbrigg for their terms as first and second vice-presidents. She also mentioned other changes among the executive committee and chairs of committees:

- Lynn Ovenden is the new recording secretary, taking over from Annie Bélair

- Annie will be the new editor of Trail \& Landscape

- Gord Robertson is the new chair of Education and Publicity

- Carolyn Callaghan has stepped down as editor-inchief of The Canadian Field-Naturalist, but will remain a director on the Board until a replacement is found

- Diane Lepage is returning to the Board, this time as first vice-president

- Jakob Mueller is the new chair of the Events Committee, taking over from Julia Cipriani

- Mark Patry will attend board meetings as the representative of the Birds Committee (but will not be a director), taking over from Rémy Poulin

- Rémy is now chair of the Finance Committee

The list of committee chairs will be approved by the Board of Directors at the April 2016 meeting.

\section{In Remembrance}

The OFNC noted with sadness the passing of Dorothy Black, long-time member of the club, on April 12, 2015 and of Garry McNulty, past president of the OFNC, on August 19, 2015.

\section{New Business and General Discussion Nil.}

\section{Adjournment}

Moved by Gord Robertson that the meeting be adjourned at 8:15 pm.

Carried

ANNIE BÉLAIR Recording Secretary 


\section{The Ottawa Field-Naturalists' Club — 2014-2015 Annual Committee Reports}

\section{Awards Committee}

The Awards Committee manages the process to annually recognize those OFNC members and other qualified persons who, by virtue of their efforts and talents, are deserving of special recognition. In 2015, nominations were received and evaluated (see awards criteria http://www.ofnc.ca/awards.php), resulting in nominees for six awards being recommended to the Board of Directors for approval. Biographies were written for each award winner for publication in the Club's journals and posting on the website. The awards were presented at the annual Awards Night in April. The recipients' names, type of award (in brackets) and rationale for recognition follow below. As well during the year, the committee worked with Mark Brenchley of the Education and Publicity Committee to update the template for the awards certificates.

- Ross Layberry (Honorary Member) - In recognition of lifetime contributions to butterfly conservation

- Natalie Sopinka (Member of the Year) - For revitalizing Club communications via social media, including the blog FieldNotes and Twitter

- Elizabeth Morton (George McGee Service Award) - For twelve years' dedicated service as the Copy Editor for The Canadian Field-Naturalist

- Anouk Hoedeman (Conservation - Member) - For creating the Ottawa Chapter of the Fatal Light Awareness Program (FLAP) and bird rescue

- Paul and Cathy Keddy (Conservation - Non-member) For land conservation achievements in the Lanark area

- Tom Spears (Mary Stuart Education Award) - For years of popularizing natural history topics for the media in the Ottawa area

Committee members: Irwin Brodo, Julia Cipriani, Christine Hanrahan, Ann MacKenzie, Karen McLachlan Hamilton.

Eleanor ZurbrigG, Chair

\section{Birds Committee}

The Birds Committee and the Club des Ornithologues de l'Outaouais organized another successful Christmas Bird Count in 2014. This event was first held in 1920 and continues to be very popular with club members and the local birding community. This year's Peregrine Falcon Watch continued only at the Heron Road site. Regrettably, most of the buildings adjacent to the downtown nest site no longer allow access to view the nest ledge making any future watch downtown logistically difficult. The Bird Records Subcommittee published a revised checklist of the Birds of Ottawa in 2015 and it is now available. The Ottawa chapter of FLAP (Fatal Light Awareness Program) left the national organization to form Safe Wings Ottawa. Safe Wings Ottawa will carry on the same work and remain affiliated with the OFNC and the Birds Committee. The committee continues to maintain a number of bird feeders in the Ottawa region.

\section{CHRIS TRAYNOR, Chair}

\section{Conservation Committee}

Three items in particular are worth mentioning:

1. Constance Bay Biothon (http://www.ofnc.ca/conserva tion/ConstanceBay/index.php):

We wrapped up field observations for this year-long (2014-2015) bioinventory at Torbolton Forest and the surrounding area. Besides engaging the local community in the practice of active Natural History observation, this project has gathered a baseline of data to compare with historical records. Analysis of data and generation of a report is to be completed over the upcoming winter season.

2. Westmeath (Gervais Caves) Bioblitz (http://www.nature conservancy.ca/en/where-we-work/ontario/featuredprojects/gervais-caves-ottawa-1.html):

On June 13th, a bioblitz inventory of the Gervais Caves property took place, organized by the Conservation Committee in partnership with Nature Conservancy Canada. Though our event only lasted the one day, we observed a number of species which had not been previously documented.

3. Mud Lake Turtle Hatchlings (https://ofnc.wordpress.com /2015/11/13/victory-for-the-snapping-turtles/):

In early 2015, our committee wrote a letter to the City of Ottawa, proposing that roadside curbs adjacent to Mud Lake be modified to allow passage of wildlife such as turtle hatchlings. We were immensely pleased that later in same year the curbs had been modified. Victory for the Snapping Turtles!

Looking forward:

We are keen to share our collective expertise with local Nature lovers. As we head into 2016, we have planned activities such as:

- Writing short seasonally-relevant "What you can do for Wildlife" articles for T\&L

- Surveys of biota at specific sites of interest (e.g., Petrie Island and Marlborough Forest) and the wider landscape

- Continuing our role as an agent for positive stewardship of the landscape through simple actions (e.g., the suggestion of curb modifications at Mud Lake).

Owen Clarkin, Chair

\section{Education and Publicity Committee}

This committee provides information to the community about natural history and the OFNC itself. This year we brought an OFNC display to several public events: Larose Forest Day in February, the Bird Day Fair at Andrew Hayden Park in May, Bug Day at the Museum of Agriculture and Food in September, and the launch of Ottawa's Urban Forest Management Plan. For youth, we judged projects at the Ottawa Regional Science Fair for OFNC's Special Awards, and presented the awards to Shamus McCoy and Allan Leveille. We selected a local high school student, Sophie Roy, for OFNC to sponsor at Ontario Nature's Youth Summit on Lake Couchiching. Committee members continued to manage the sales table at monthly meetings and OFNC's blog and twitter account. Over 20 social and educational groups in the region requested a nature walk or talk from OFNC; many thanks to those members who respond to such requests and share their knowledge with others.

Late in 2014, OFNC launched an ongoing project to improve its communications both internally with members and with the broader community. For help, we engaged Village PR to conduct a survey of members' preferences and an inventory of OFNC's many communications channels. Village PR recommended several ways that OFNC communications could better meet the information needs of members and support the club's objectives of enhancing the appreciation and conservation of nature.

LYNN Ovenden, Chair 


\section{Events Committee}

The Events Committee coordinated 63 outings, five workshops, 10 monthly meetings and the annual awards celebration. The outings and workshops included: amphibians and reptiles (3), birds (32), butterflies and moths (3), other insects (6), plants/trees (9), geology (1), photography (3), general natural history (11).

The Events Committee planned, coordinated or supported:

- 61 outings, seven of which were workshops

- 10 monthly meetings, including the annual business meeting; unfortunately the December 2014 monthly meeting was cancelled because the meeting room was not available

- 2015 Awards celebration at St. Basil's Church, held on April 18.

The focus of outings, workshops and monthly meetings included birds (18), plants/trees (16), general natural history (12), amphibians and reptiles (5), travel (4), mineralogy (3) insects (3), photography (3), butterflies and moths (2), conservation (1), fungi (1) and geology (1).

Jon Ruddy led an informal migration watch on Greenland Road and posted results on Facebook over several weeks to track the migration of hawks, eagles, falcons and vultures.

Two outings planned for sparrow spotting on Ottawa airport land were cancelled when access to the area was blocked.

Lynn Ovenden, Chair of Education and Publicity, led the planning of four events over the May long weekend to explore the Gervais property with Ali Giroux, NCC, afternoon birding with Christian Renault, Pembroke Area Field Naturalists, an evening mothing outing with Diane Lepage and a guided tour of Shaw Woods with Grant Dobson.

Sandra Garland and Isabel Nicol led a total of 11 tours - nine of the Fetcher Wildlife Garden, two of the backyard garden.

Monthly meetings were held in Salons A \& B of the Neatby Building. The January business meeting was held at the Fletcher Interpretation Centre.

Committee members: Holly Bickerton, Julia Cipriani (chair), Owen Clarkin, Chair of Conservation, Hume Douglas, Jakob Mueller.

If you have ideas for events or would like to lead an outing or event, please contact Jakob Mueller, incoming chair, (jm $890 \_7$ AT hotmail DOT com) or other members of the committee.

Julia Cipriani, Committee Member

\section{Finance Committee}

The OFNC's financial reporting systems are operating smoothly and efficiently. In addition the interim financial reports that are prepared several times a year by the Treasurer are also useful. These reports provide the OFNC committees with a snapshot of the year-to-date status of OFNC's revenues and expenses.

The preparation of the 2016 OFNC budget was a less onerous task this year as committees have several years of experience now in preparing a budget. Committees are also using the budget process as a planning tool for the coming year. Special projects and new initiatives are brought forward to the OFNC board for discussion and if approved, the item is included in the budget.

The draft 2016 OFNC budget was discussed in detail at the September 2015 board meeting and the revised budget was approved at the October 2015 meeting. The 2016 OFNC budget forecasts a substantial deficit however the OFNC has the funds to cover the shortfall as a result of the significant bequest to the OFNC.
During the 2015 fiscal year, the Finance Committee responded to issues raised by the board which included donations in kind, investment guideline policy, and preliminary succession planning for the Treasurer position. In addition the Finance Committee updated its Terms of Reference and the OFNC Financial System summary.

The Finance Committee continues to promote fiscal responsibility and the OFNC's financial reports reflect this operating mandate.

BARbara ChOUINARD, Chair

\section{Fletcher Wildlife Garden (FWG) Volunteers}

Much appreciation was shown by all our visitors for our work in the Back Yard Garden. Comments made about the feeling of serenity that many feel when they visit, as well as their comments on the colourful plants and their placement which adds to its beauty. This is work accomplished by mowing, keeping the paths clear, tending the feeder and birdbath, and the weeding and care of all the plants. This is accomplished by all of our dedicated volunteers who put in a great deal of work to help keep the garden at its spectacular best throughout the spring, summer and fall.

FWG volunteers have come from Volunteer Ottawa; young high school students wishing to fulfill their volunteer hours; and students from Carleton University; Carleton Serves day; the Tamir Youth group; The Ernst \& Young community volunteer program.

Over 4000 volunteer hours were used in 2015 to help the Fletcher Wildlife Garden to preserve and protect this unique green space in Ottawa.

\section{Annual Plant Sale}

Our annual plant sale raised almost $\$ 5000$ this year. The success can be partly attributed to help from a Carleton student intern. We continue to sell and donate plants to schools and community gardens, in cooperation with Nature Canada, Evergreen schools programs, and independently. This is one of the FWG's largest activities, providing both additional revenue and good public visibility.

We also continue to sell and donate plants to schools and community gardens, in cooperation with Nature Canada, Evergreen schools programs, and independently.

\section{Visitors, Tours, Walks, and Workshops}

We don't have any means of counting the number of visitors that come to the FWG, but the Garden did have a large number of local, out-of-town, and foreign visitors.

We held a series of nature walks every second Sunday afternoon with mixed success. Several walks attracted up to 20 participants and brought us new volunteers and "friends".

A workshop to build simple mason bee boxes was held in April and two boxes were installed in our bee hotel. They were used by Blue Orchard Mason Bees. We also inherited AAFC bee boxes and are working on a cycle of monitoring, cleaning, and storing cocoons safely over winter in consultation with a bee expert from Ottawa University.

\section{Community Outreach}

We contributed seeds and plants to the new Canadian Museum of Nature ecozones garden and we helped create a demonstration pollinator planter box next to the Horticulture Building at Lansdowne Park. 


\section{New Shed}

The tool and equipment inventory for the FWG continues to grow, and storage space had become a problem. A second garden shed (identical to the first one) was purchased to allow more storage space. Items from the Interpretation Centre, the old small tin storage shed and the nursery were moved into the new shed. The company that installed the new shed donated a new bird bath for the Back Yard Garden.

\section{Interpretation Centre (IC)}

In the fall of 2015 the Interpretation Centre was cleaned and painted indoors, resulting in a fresh look. The storage area was de-cluttered and new shelving purchased; this work was supported by a donation to the OFNC. The kitchen area was re-organized and enhanced, but the installation of a sink was not possible. Discussions have started about putting a door on the east wall of the IC for safety reasons.

The IC now has internet hook up.

\section{Old Woodlot Rehabilitation}

To address the loss of over 50 ash trees from our Old Woodlot, we formed a Tuesday afternoon volunteer group that planted a variety of trees, shrubs, and wildflowers. Invasive species continue to plague all areas, but control measures are improving as we learn more.

A fall Carleton Serves day resulted in another large area of the Old Woodlot being cleared of Dog Strangling Vine (DSV) and gained us another regular volunteer.

To further our role as a Monarch Waystation, last year's Youth Summit participant and her friends planted hundreds of milkweed seeds in the field north of our Old Woodlot.

\section{Memorials}

This year a memorial plaque was put on the new bird feeder to commemorate Charles Clifford (an ex OFNC Board member, long time birder, and FWG volunteer). The Cody Trail including the new fern garden was dedicated, and finally, a tree was planted with a plaque to commemorate Laurie Consaul.

\section{The Pond}

The pond rejuvenation project was put on hold in November 2014. Two items prevented us from moving forward. We had to get sediment samples to find out if the sediment in the pond is contaminated, and we also needed to get someone from SARA to evaluate the possible risk of having a negative impact on turtles, even though we had no Blanding Turtles visiting the pond since 2010 .

The Paterson Group was hired to take sediment samples and have them characterized. The Ottawa Field-Naturalists' Club agreed to cover the expenses. As of December, test results have not been received back.

This summer the pond was covered of vegetation which meant less wildlife was resident. Removal of invasive plants from the pond by four Kemptville Youth Rangers and their leader, together with FWG volunteers, created an opening that attracted ducks that helped reduce the duck weed that was covering the surface of the pond.

Plans to do the "path project" around the pond will continue regardless of the pond rejuvenation work.

\section{Butterfly Meadow (BM)}

Work in the Butterfly Meadow occurred most Wednesday evenings throughout the summer. During the first months we removed the dead vegetation and prepared the garden for the season. Throughout the summer we worked at improving the BM by planting flowers and weeding.

The volunteers cleared a few areas where DSV predominated and replaced them with flowers. We also put old newspapers or pool liners around trees and shrubs and then covered them with wood chips. The intention is to minimize weeding in the future years and stop the DSV from spreading.

We also maintained the previously planted areas, and worked at removing the plants that are spreading aggressively. To further our role as a Monarch Waystation, last year's Youth Summit participant and her friends planted hundreds of milkweed seeds in the field north of our Old Woodlot.

\section{Nodes}

A new initiative this year was a call for volunteers who are interested in adopting a small area and working independently - with guidance and help from the Management Committee. So far, seven people are tackling "nodes", removing invasives and planting native species. Education nodes, places where we have a "story" to tell our many visitors, have been identified and bilingual signs are being prepared for the 2016 season.

\section{Invasive Species}

The buckthorn does not go away, though the remaining trees are much bigger or else they appear from places which are difficult to access. A lot of time was spent on another invasive tree which is proving difficult to control. In the three known sites with Euonymous europeii (European Spindle) they are now more widespread and harder to get at than when they were first noticed. The trees are smaller but spread through the roots.

The three volunteers of the Wednesday Invasive Species Group put in over 100 hours in the 2015 season. We continued working eight small plots on the perimeter of the Butterfly Meadow, using several techniques for controlling DSV, including tarping, mowing / reseeding and digging / reseeding. A 100 $\mathrm{m}^{2}$ test area was cleared just outside the BM with a view to systematically monitoring the effects on DSV of several treatment manual methods. In the New Woods, a large tarp laid down last year was taken up, DSV and other plants growing below it cleared out so the tarp could be put back down. Work removing Asian Bittersweet and other invasives continued in the Birch Grove. Rapidly regenerating non-native birches were pruned back from the surviving native birches planted. A number of other trees in these areas were pruned as needed, to remove dead wood and alleviate crowding by invasives. The AAFC mowed the field south of the pond and resprayed the glyphosate test spray area in the New Woods. Encouraged by the positive results of two years of treatment, we prepared and seeded a $100 \mathrm{~m}^{2}$ portion of the test area that we will be monitoring for the next few years.

Burdock and Purple Comfrey have been identified as invasive species to address. However, no concerted efforts have been directed towards these invasives as yet.

\section{The Back Yard Garden (BYG)}

A lot of work was accomplished this year in the BYG. The usual weeding, transplanting, and mulching was accomplished with a number of new volunteers as well as the ones who have been with us for many years now.

We had many visitors again this year. They included people purposely visiting the garden itself, people making the garden 
a part of their walk on their way to visit other areas, people walking their dogs, cyclists, birders, photographers, etc. And perhaps, most importantly, people visiting because of "word of mouth"; people who heard about us through friends and family. We left the bird feeder up, for the first time throughout this summer; the feeder was a popular attraction both for birds and photographers. Many people would come just to sit and watch the many birds at the feeder, as well as the squirrels, rabbits, and chipmunks interacting with one another beneath the feeder.

The most interesting and exciting aspect of this year's work was incorporating a Fern Trail in the BYG which honours William J. (Bill) Cody; a beautiful area which has become a major attraction for our many visitors.

We are in the process of getting signs created for all the plants in the garden.

There has been more ongoing work with keeping DSV from invading the BYG. Tarpaulins were laid down at the back of the garden where the problem gets worse each year, as well as in the surrounding areas. The plan is to put down these large tarps, cover them with brush piles, etc., and hope that they help hold back the invasion.

TED FARNWORTH, committee representative on board of directors

\section{Macoun Club Committee}

The Committee, whose members generally all see each other at the weekly events, put together the month-to-month program for the children without the need for committee meetings. The weekly schedule and an illustrated record of what was done were maintained on the Club's website (macoun fieldclub.ca). Saturdays, Committee members supervised or gave presentations at the 2-hour-long indoor meetings (held in the Fletcher Wildlife Garden's interpretation centre) or led the 5- to 6-hour-long field trips. Most field trips took place either on private properties in Lanark County or in the Club's nature-study area of 45 years standing in the National Capital Commission's greenbelt (Stony Swamp), but there was also a bus trip to the Montreal Ecomuseum (paid for by the Camfield Memorial Fund). Funds donated in memory of former member Bob Bracken were used to buy enough birding field guides to pass around the table when sharing observations at all indoor meetings. The Committee produced issue no. 69 of the Club's annual publication, The Little Bear, and distributed it to members.

Outside the scope of normal activities, the Committee approved and facilitated the participation of Macoun Club members with a graduate student, who was studying children's understanding of, and attitudes toward, climate change. Com- mittee members also scouted out specific locations for the filming of particular forest invasives in the Macoun NatureStudy Area at the request of the Invasive Species Centre, and conducted the video crew and expert narrators to each spot. At summer's end, the Macoun Club led a special field trip in their Study Area for OFNC members.

Robert E. LeE, Chair

\section{Membership Committee}

The distribution of Club membership for 2015 on 30 September 2015 is shown in the table below, with the corresponding numbers shown in brackets for 30 September 2014. "Other" represent mostly affiliate organizations that receive complimentary copies of the Club's publications. The Board implemented a new policy in 2014 that the family of children in the Macoun Club be given a complimentary membership to encourage interest in the Club in the longer term. The effectiveness of this policy will be reviewed in 2017. The number of new paying members of 133 was consistent with the 130 in 2014. The increase in total paying membership of 19 (Macoun Club members excluded) maintained the growth note in 2014 and was due to higher current-member renewal. The increase in Student Membership to 27 is a positive sign for the Club.

HENRY STEGER, Chair

\section{Publications Committee}

The Publications Committee manages publication of the Club's scientific journal The Canadian Field-Naturalist (CFN), the Club's newsletter Trail \& Landscape, and Special Publications. Publications Committee members in 2015 were Dan Brunton, Carolyn Callaghan (Editor-in-Chief, CFN), Paul Catling, Jay Fitzsimmons, William Halliday, Sandra Garland, Tony Gaston, Amanda Martin (Assistant Editor, CFN, vol. 129(2) onwards), Karen McLachlan Hamilton (Editor, Trail \& Landscape), Frank Pope, Trina Rytwinski (Assistant Editor, CFN, up to vol. 129(1)), Jeff Saarela (Chair), and David Seburn. Committee meetings were held on 5 February and 5 October 2015, and a variety of issues pertinent to the management of the Club's publications was discussed. The committee began a process of evaluating the current formats (the "look and feel") of both The Canadian Field-Naturalist and Trail \& Landscape, with the intent of eventually re-designing one or both of these publications.

Publication of The Canadian Field-Naturalist proceeded smoothly and on-time in the last years, and four issues were published in 2015: 128(4) (mailing date 30 January 2015), 129(1) (5 May 2015), 129 (2) (4 August 2015) and 129(3) (23 October 2015). The final issue of volume 129 is expected to be

\begin{tabular}{|c|c|c|c|c|c|c|c|c|}
\hline & \multicolumn{2}{|c|}{ CANADIAN } & \multicolumn{2}{|c|}{ USA } & \multicolumn{2}{|c|}{ OTHER } & \multicolumn{2}{|c|}{ TOTAL } \\
\hline & 2015 & 2014 & 2015 & 2014 & 2015 & 2014 & 2015 & 2014 \\
\hline Individual & 359 & (354) & 9 & $(10)$ & 0 & $(0)$ & 368 & (364) \\
\hline Family & 309 & (296) & 1 & $(0)$ & 1 & (1) & 311 & (299) \\
\hline Student & 27 & (20) & 0 & $(0)$ & 0 & (0) & 27 & (20) \\
\hline $\mathrm{T} \& \mathrm{~L}$ & 1 & (1) & 0 & (0) & 0 & (0) & 1 & (1) \\
\hline Honorary & 24 & (23) & 0 & (0) & 0 & (0) & 24 & (21) \\
\hline Life & 44 & (45) & 3 & (3) & 1 & (1) & 48 & (49) \\
\hline Other & 30 & (25) & 0 & (0) & 1 & (1) & 31 & (26) \\
\hline Macoun Club & 17 & & & & & & 17 & \\
\hline TOTAL & $\overline{811}$ & $\overline{(764)}$ & $\overline{13}$ & $\overline{(13)}$ & 3 & (3) & $\overline{827}$ & $\overline{(780)}$ \\
\hline
\end{tabular}


published in early January 2016, and upon completion volume 129 will comprise well over 400 pages reporting the results of important natural history research in Canada and on species that occur in Canada, numerous book reviews, and the official minutes of the 136th Annual Business Meeting of the Ottawa Field-Naturalists' Club. In 2015, Assistant Editor Trina Rytwinski retired after completion of 129(1), having served in production of 17 issues of CFN. Trina's work on behalf of the committee and the Club was extremely important during a time of editorial transition. Following Trina's departure, the committee welcomed new Assistant Editor Amanda Martin, who commenced her work with the journal starting with volume 129(2). In late 2015 Roy John, Book Review Editor for CFN, tendered his resignation. Roy served in this capacity since 2003; he has authored over 250 reviews in CFN, and handled all the reviews by others. The new CFN Book Review Editor is Mark Gawn. Ken Young provided extensive and much-appreciated help bringing order to The Canadian FieldNaturalist subscriptions, page charge invoices and budget tracking. Jay Fitzsimmons continued to tweet on Twitter on behalf of the journal under the handle @CanFieldNat throughout 2015, in a fun and engaging way, drawing attention to new and earlier papers published in The Canadian Field-Naturalist. By the end of $2015 @$ CanFieldNat had over 2,600 followers.

Four issues of Trail \& Landscape were produced by Editor Karen McLachlan Hamilton and her team in the current year. Trail \& Landscape continues to provide an important newsletter function informing Club members of current and upcoming activities, and it is a significant source of documentation of regional biodiversity and conservation needs.

The committee worked with the Bird Records Subcommittee on publication of an updated Bird Checklist for the Club's study area.

In 2015 the Publications Committee started a new initiative: the Ottawa Field-Naturalists' Club Research Grants program. Research grants support field-based research activities that reflect and promote the Club's objectives within eastern Ontario or western Quebec, focused particularly upon the Club's study area - inside the $50 \mathrm{~km}$ radius from the Peace Tower in Ontario or Quebec. A total of $\$ 15,000$ is available each year to fund research proposals. The committee developed guidelines for the research grants, put out the first call for proposals in April 2015, and awarded the first round of research grants in June 2015. The OFNC Research Grants Subcommittee (a subcommittee of the Publications Committee) was established, chaired by Tony Gaston, to receive and evaluate research proposals. The 2016 Call for Proposals went out in November 2015.

In the inaugural year of the program, 11 proposals were received and the following eight were funded:

1. Chelsey Blackman, M.Sc. candidate, Carleton University. Host range of Lilioceris lilii and ability of biocontrol agent Tetrastichus setifer to find pest on novel hosts. Awarded \$2066.

2. Henri Goulet \& P.T. Dang, Biodiversity Conservancy International. Study of the Ghost Tiger Beetle (Ellepsoptera lepida) population in the Pinhey Sand Dunes. Awarded \$2066.

3. Jean Faubert, Société québécoise de bryologie. Flore du parc de la Gatineau/Gatineau Park Flora. Awarded $\$ 2066$.

4. Stephanie Haas, M.Sc. candidate, University of Ottawa. How do environment and host phylogeny influence mite communities on bumblebee species? Awarded \$2066.

5. William Halliday, Ph.D. candidate, University of Ottawa.
What ecological factors are most important to habitat selection by Common Gartersnakes (Thamnophis sirtalis) in the National Capital Region? Awarded \$2066.

6. Marry Ann Perron, M.Sc. candidate, University of Ottawa. Biodiversity in urban stormwater management ponds: effects of pond age and water quality. Awarded \$2066.

7. David Seburn, Seburn Ecological Services. Have salamanders declined in eastern Ontario? Awarded \$1100.

8. Richard Webster (postdoctoral fellow, Carleton University) and Jim des Rivières (independent researcher). Evidence-based moth catching: designing small, inexpensive and low energy lights for mothing. Awarded $\$ 1500$.

JefF SAAREla, Chair

\section{Treasurer's Report}

\section{Financial Statements}

The financial statements have been prepared by our accounting firm, Welch LLP. They have conducted an engagement review of our financial records.

The Club financial statements are prepared using the fund method of accounting. In the financial statements, the first table (page 2) presents the financial position of all the Club's funds in a consolidated manner. The remaining tables present the statement of operations of the general fund (page 3 ), the internally restricted funds (page 4) and our one endowment fund (page 5). There is also a cash flow presentation (page 6). The Notes to the financial statements explain the Club's financial policies.

The Notes include a presentation of our long-term investments. Our investments are made according to a policy established by the Board of Directors, and implemented by Ann MacKenzie and our investment advisor, Sue Anderson of BMO Nesbitt Burns.

As in the past, we have received excellent service from our accounting firm, Welch LLP, and our reviewer, Eric Liebmann, to whom I give thanks.

\section{Financial Position}

The Club improved its financial position in the 2014-2015 fiscal year as the remainder of Violetta Czasak's bequest was recognized in our accounts. As a result, the total assets of the Club are $\$ 1,617,722$.

The major sources of revenue for the Club are membership fees, donations and bequests, and subscription charges and authors' charges for the Canadian Field-Naturalist.

Both membership and CFN revenues have increased. Donations and bequests, other than the Czasak bequest, are also up.

Expenses were also stable during the year, after allowing for increased donations that the Club has made. In 2015, the Club used revenues from the Czasak bequest to help preserve natural areas and to assist other charities in the area. It also established a research grant program to encourage research in natural history.

\section{Violetta Csazak Bequest}

The Club received a large bequest from Violetta Czasak, who died in 2013. Because of the size and complexity of the estate, it has taken a couple of years to liquidate the assets. However, that has been done and the 2014-2015 financial statements reflect the final results, barring anything unexpected.

The net disbursements to the Club total $\$ 1,235,226$. The gross value of the estate was $\$ 1,297,662$. Expenses of $\$ 62,436$ were incurred in liquidating the estate. 


\section{Budget for the 2015-2016 Fiscal Year}

The Board approves the budget for the Club at the October meeting of the Board of Directors. The budget is attached to the minutes of that meeting and is available on the OFNC website where minutes of Council meetings are kept, at http: //ofnc.ca/council/minutes.php.

This year, the budget includes revenues of $\$ 122,550$ and expenses of $\$ 169,005$. Therefore we are budgeting for a deficit of over $\$ 45,000$. This pattern will likely be repeated for at least several years, because we do have to spend the Czasak bequest. There is no rush to do this, but the regulations that govern charities discourage them from sitting on their financial resources.

As I mentioned, the Club has made expenditures that are directly related to our charitable objects. More are planned. The research grant program will continue, and we are exploring the possibility of funding increased use of the MacSkimming Outdoor Education Centre. We are also making some overhead expenditures. For example, we have renovated the Fletcher Interpretive Centre. It is heavily used and the renovation makes it more comfortable and efficient. We are also in the process of modernizing our website.

\section{Routine Events}

Most of the Treasurer's duties continue from one year to the next. They include:

- filing the Charities Information Report with the Canada Revenue Agency;

- preparing T4A returns for people receiving honoraria or contract fees from the Club;

- updating the Club's information with our bank, the Canadian Imperial Bank of Commerce, and our online payments processor, PayPal;

- depositing cheques received and writing cheques to pay expenses;

- making financial reports to Council and Committees, such as for the Canadian Field-Naturalist, the Seedathon, the Fletcher Wildlife Garden and the Macoun Field Club; and

- assisting the reviewer in the production of the annual financial statements.

I would again like to express my appreciation for all the assistance that I have received from Frank Pope, the past Treasurer, and Ann MacKenzie, who handles the investment activities of the Club. 


\section{Review Engagement Report}

To The Members of The Ottawa Field-Naturalists' Club

We have reviewed the statement of financial position of the The Ottawa Field-Naturalists' Club as at September 30, 2015 and the statements of operations, changes in fund balances and cash flows for the year then ended. Our review was made in accordance with Canadian generally accepted standards for review engagements and accordingly consisted primarily of enquiry, analytical procedures and discussion related to information supplied to us by the club.

A review does not constitute an audit and consequently we do not express an audit opinion on these financial statements.

Based on our review, nothing has come to our attention that causes us to believe that these financial statements are not, in all material respects, in accordance with Canadian accounting standards for not-for- profit organizations.

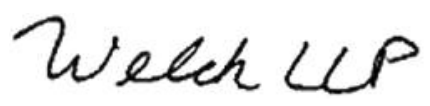

Ottawa, Ontario

CHARTERED ACCOUNTANTS Licensed Public Accountants

February 15, 2016
The Ottawa Field-Naturalists' Club

Statement of Financial Position

September 30, 2015

2015

2014

Assets

Current Assets

Cash \$ 383,267 \$228,120

Short-term investments (note 4) $\quad 145,803 \quad 70,622$

Amounts receivable $\quad 89,226 \quad 16,802$

Prepaid expenses

3,813

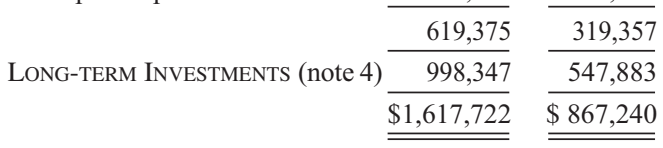

Liabilities ANd Fund Balances

CuRrent Liabilities

Accounts payable and

accrued liabilities

Deferred revenue

\begin{tabular}{l}
$\$ \quad 2,755 \quad \$ \quad 3,382$ \\
\hline
\end{tabular}

Deferred revenue

FUND BALANCES

General fund

$\begin{array}{r}12,481 \\ \hline 15,236 \\ \hline\end{array}$

12,953
16,335

Internally restricted funds

$1,298,752$
266,112

552,505

Martha Camfield

endowment fund

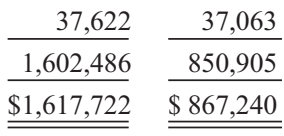

Approved by the Board:

President

Treasurer 


\section{The Ottawa Field-Naturalists' Club \\ Statement of Operations and Changes in Fund Balance \\ - General Fund}

Year Ended September 30, 2015

REVENUES
Membership fees
Bequests
Donations
The Canadian Field-Naturalist
- subscription revenue
- author charges
Pelee trip
Interest
Advertising
Other

2015

2014

$\$ \quad 28,243$

EXPENSES

OPERATING:

Affiliation fees

Bookkeeping

Courier and postage

Insurance

Interest and bank charges

Membership

Professional fees

Website

Maintenance

General and miscellaneous

ACTIVITY:

The Canadian Field-

Naturalist

Fletcher Wildlife Garden

Awards committee

Soiree - net

Birds committee

Donations

Education and publicity

Excursions and lectures

Macoun Club

Pelee trip

Trail and Landscape

Research grants

\section{TOTAL EXPENSES}

Net Revenue

Fund Balance,

BEGINNING OF YEAR

Inter-fund transfer -

internally restricted funds

Fund Balance,

END OF YEAR
973,781

4,124

22,255

41,487

21,943

675

3,754

$\overline{1,096,262}$

$\begin{array}{r}\$ 27,873 \\ 261,987 \\ 5,068 \\ \\ 23,357 \\ 27,645 \\ 14,937 \\ 13,961 \\ 150 \\ 1,905 \\ \hline 376,883 \\ \hline\end{array}$

422

2,424

797

1,728

1,379

1,201

2,723

2,000

1,650

2,237

16,561

\begin{tabular}{rr}
76,857 & 78,758 \\
4,360 & 1,680 \\
523 & 65 \\
518 & 138 \\
5,554 & 984 \\
214,500 & 5,000 \\
11,441 & 2,612 \\
136 & 1,547 \\
137 & 241 \\
- & 12,483 \\
8,059 & 7,318 \\
11,369 & - \\
\cline { 2 - 2 } 333,454 & 110,826 \\
\hline
\end{tabular}

$\begin{array}{ll}350,015 & \frac{129,260}{746,247}\end{array}$

1,246

892

4,130

2,078

1,755

2,697

18,434
The Ottawa Field-Naturalists' Club

Statement of Changes in Fund Balance - Martha

Camfield Endowment Fund

Year Ended September 30, 2015

2015

2014

Fund BALANCE,

BEGINNING OF YEAR

Interest earned

$\$ 37,063 \quad \$ 36,482$

Fund BALANCE, END OF YeAR

$\$ 37,62$

$\$ 37,063$

Note: The interest above represents half of the interest generated by the fund and is re-invested in the capital of the fund. The other half of the interest generated by the fund is recognized as interest revenue of the Macoun Fund (see Statement of Operations and Changes in Fund Balances - Internally Restricted Funds) and is made available for the use of the Macoun Field Club.

\section{The Ottawa Field-Naturalists' Club}

Statement of Cash Flows

Year Ended September 30, 2015

Cash Flows from Operating

\section{Activities}

Net revenues - all funds

Change in the level of:

Amounts receivable

Investments

Prepaid expenses

Accounts payable and accrued liabilities

Deferred revenue

2015

2014

\section{Cash Flows from Investing}

Activities

Purchase of investments

Proceeds from maturity

of investments

$\$ 751,022 \quad \$ 252,258$

$(72,424)$

7,578

$(23,060)$

$(16,481)$

2,734

$(3,180)$

(627)

(472)

(200)

657,173

$(723,905)$

$(64,568)$

221,320

$(502,585)$

$(64,568)$

\section{Cash Flows from Financing}

Activities

Endowment interest earned

Increase in Cash

$\frac{55}{155,14}$

581

Cash at Beginning of Year

228,120

172,258

Cash at End of Year

(See accompanying notes) 


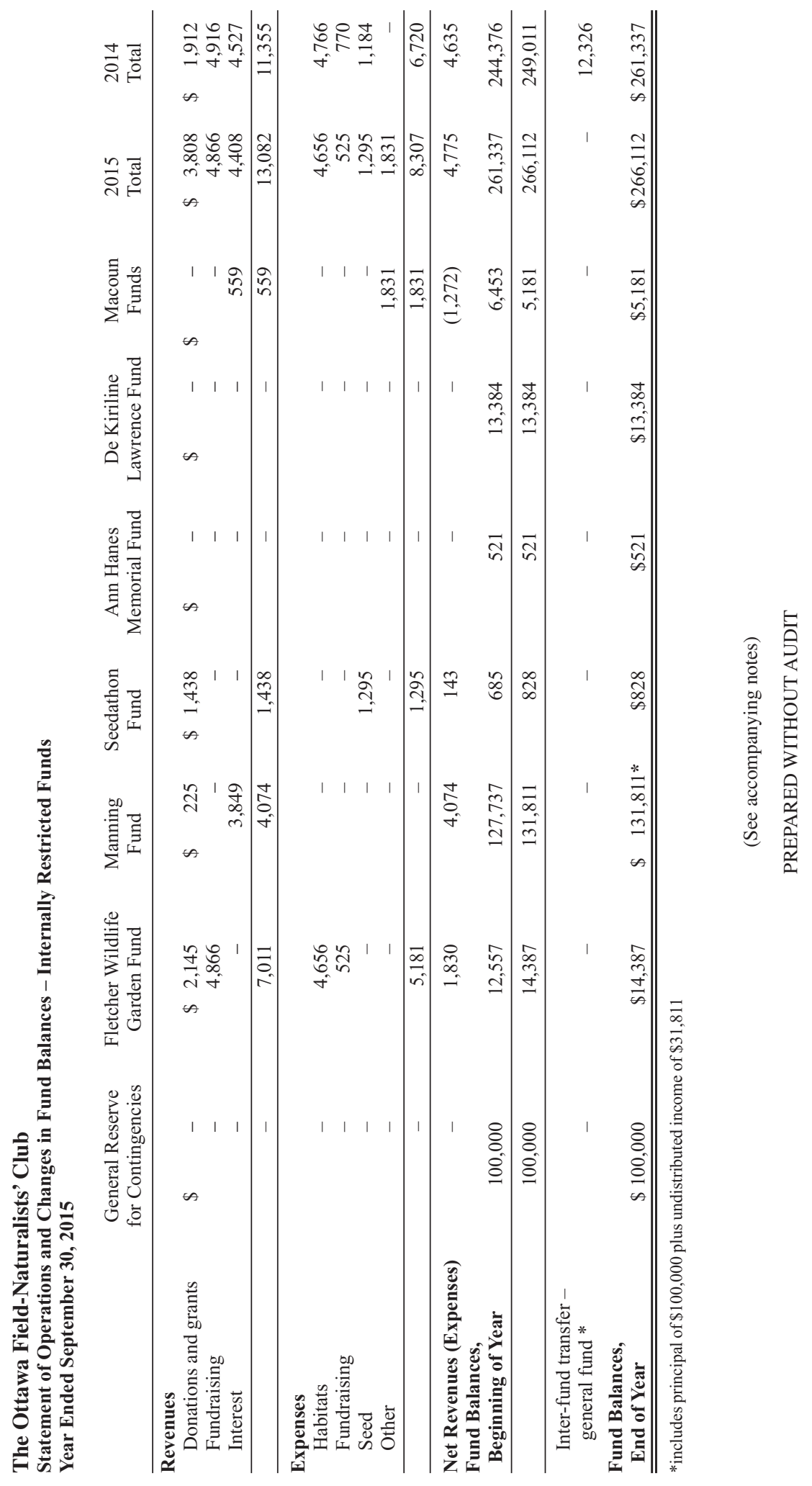




\section{The Ottawa Field-Naturalists' Club Notes to the Financial Statements Year Ended September 30, 2015}

\section{Purpose of Organization and Tax Status}

The Ottawa Field-Naturalists' Club (the "club") is a volunteer, registered charitable organization incorporated under the Corporations Act of the Province of Ontario. The objectives of the club are to promote the appreciation, preservation, and conservation of Canada's natural heritage and to encourage investigation and dissemination of the results of research in all fields of natural history.

The club's operations are overseen by a Board of Directors (the "board"). Club activities are undertaken by club members participating in standing committees.

As a registered charity the club is exempt from income taxes by virtue of section 149(1)(f) of the Income Tax Act (Canada).

\section{Significant Accounting Policies}

Basis of accounting

These financial statements have been prepared in accordance with Canadian accounting standards for not-for-profit organizations.

\section{Revenue recognition}

(i) Membership fees are recognized as revenue proportionately over the fiscal year to which they relate. The club's membership year is January 1 to December 31. The portion of membership fees that are received but not yet recognized as revenue are recorded as deferred revenue.

(ii) The club follows the deferral method of accounting for contributions. Restricted contributions are recognized as revenue in the year in which the related expenses are incurred. Unrestricted contributions are recognized as revenue when received or receivable if the amount to be received can be reasonably estimated and collection is reasonably assured. Endowment contributions are recognized as direct increases in net assets. The club only recognizes revenue from bequests if the will has been probated, a valuation has been received from the executor of the estate and collection can be reasonably assured. Otherwise, revenue from bequests will be recognized as the amounts are received.

(iii) Subscription revenue and author charges are recognized as revenue at the time of release and shipment of the related Canadian Field-Naturalist publication. The liability for the portion of subscription revenue and author charges invoiced in advance of the release and shipment of the related publication is recorded as deferred revenue.

(iv) Trip revenue is recognized at the conclusion of the related field trip. Amounts collected in advance of field trips that have not yet taken place is recorded as deferred revenue. (v) Interest income comprises interest from cash and investments. Interest on investments is recognized over their term using the effective interest method. Interest income derived from the investment of restricted contributions, where the contribution agreement specifies that the investment income is restricted, is accounted for the same manner as the restricted contributions.

(vi) Advertising revenue is recognized in the period in which the advertisement is published.

(vii) Fundraising revenue is included in the statement of operations upon completion of the fundraising event.

(viii) Other revenue includes royalties and the sale of other products and services. Revenue from royalties is recognized in accordance with the terms of the related agreement. Revenue from the sale of other products and services is recognized at the time of delivery or when the service has been rendered.

\section{Fund accounting}

The Club maintains its accounts in accordance with the principles of fund accounting. Resources are classified for accounting and reporting purposes into funds according to the activity or object specified.

\section{General Fund}

The General Fund reports the revenue and expenses relating to general operations and administration activities.

\section{Internally Restricted Funds}

(i) General Reserve

The General Reserve for contingencies was established by the Club to fund outstanding operating expenses should the Club discontinue its operations.

(ii) Fletcher Wildlife Garden Fund

The Fletcher Wildlife Garden fund supports the habitat development at the Fletcher Wildlife Garden, with income directed donations and the proceeds for the annual plant sale.

(iii) Manning Fund

The Manning fund was established by a bequest, and the interest generated is used to assist authors to publish articles in the Canadian Field Naturalist.

(iv) Seedathon Fund

The Seedathon fund collects donations from the annual bird sighting event and purchases seed for the Club's bird feeders. 


\section{(v) Anne Hanes Memorial Fund}

The Anne Hanes Memorial fund was raised in memory of Anne Hanes, the founding editor of Trail and Landscape, and is used to finance the annual winners of the Anne Hanes Natural History Award.

(vi) De Kiriline-Lawrence Fund

The de Kiriline-Lawrence fund was funded by a bequest from the popular author of nature books, and is supplemented by annual donations and used to support conservation efforts.

\section{(vii) Macoun Funds}

The Macoun Funds comprises of two internally restricted funds, the Martha Camfield Memorial fund and the Macoun Baillie Birdathon fund. The former is used to support special projects of the Macoun Field Club, a youth club. The latter was raised from donations made during the Baillie Birdathons. Its purpose is to support bird research by a Macoun Field Club youth member.

\section{Martha Camfield Endowment Fund}

The Martha Camfield endowment fund was established by the family and friends of Martha Camfield to help continue her efforts to have children study, understand, respect and preserve their natural environment. Under the terms of endowment agreement half of the interest generated by the fund is re-invested in the capital of the fund while the other half is credited to the Martha Camfield Memorial fund and made available for use by the Macoun Field Club. In the Statement of Operations and Changes in Fund Balances - Internally Restricted Funds, the Martha Camfield Memorial Fund and the Macoun Baillie Birdathon Fund have been combined and presented as the Macoun Funds.

\section{Internally restricted net assets}

Internally restricted net assets represent the amount approved by the board to be set aside for special purposes. These amounts are not available for unrestricted purposes without the approval of the board.

\section{Financial instruments}

The club initially measures its financial instruments at fair value upon initial recognition. The club's cash is subsequently measured at fair value. All other financial instruments are measured at amortized cost at the date of the financial statements.

\section{Donated services}

The club is dependent on the voluntary service of many of its members. As there is difficulty in determining the fair value of voluntary services, they are not recognized in these financial statements.

\section{Use of estimates}

The preparation of financial statements in conformity with Canadian accounting standards for not-for-profit organizations requires management to make estimates and assumptions that affect the reported amounts of assets and liabilities and disclosure of contingent assets and liabilities at the date of the financial statements and the reported amounts of revenues and expenses during the reporting period. Actual results could differ from those estimates.

Management makes accounting estimates in the determination of the club's potentially uncollectible amounts receivable and in the estimation of the club's accrued liabilities.
By their nature, these estimates are subject to uncertainty and the impact on the financial statements of the current future periods could be material.

\section{Financial Instruments}

The club is exposed to various risks through its financial instruments. The following analysis provides a measure of the club's risk exposure and concentrations as at September 30, 2015.

\section{Credit risk}

Credit risk is the risk that one party to a financial instrument will cause a financial loss for the other party by failing to discharge an obligation.

The club's maximum exposure to credit risk represents the carrying value of its cash, amounts receivable and investments totalling $\$ 1,616,643(2014-\$ 863,427)$.

The club's cash is deposited with Canadian financial institutions. As a result, management believes the risk of loss on cash to be unlikely.

The company provides credit to authors of the Canadian Field-Naturalist publication in the normal course of operations. It carries out, on a continuing basis, a review of outstanding amounts and maintains a provision for uncollectible accounts. Management has established an allowance for doubtful amounts receivable at September 30, 2015 of $\$ 1,500$ (2014 - \$nil) that represents management's best estimate of potentially uncollectible accounts.

Investments primarily consist of provincial bonds backed by provincial governments and guaranteed investment certificates issued by Canadian financial institutions of high credit quality. Possible changes to the credit quality of these securities exposes the club to credit risk. The club manages its exposure to this risk by holding a diversified portfolio with varied maturities. The club reduces its exposure to credit risk on its amounts receivable by reviewing the accounts on a regular basis, following up on outstanding amounts and creating an allowance for doubtful accounts when applicable.

\section{Liquidity risk}

Liquidity risk is the risk that the club cannot meet its debts when they become due. Liquidity risk also includes the risk of the club not being able to liquidate assets in a timely manner at a reasonable price.

The club meets its liquidity requirements by monitoring its expected future cash flow requirements and holding a significant amount of assets that can be readily converted into cash.

\section{Market risk}

Market risk is the risk that fair value or future cash flows of a financial instrument will fluctuate because of changes in market prices. Market risk is comprised of currency risk, interest rate risk and other price risk.

\section{(i) Currency risk}

Currency risk refers to the risk that the fair value of financial instruments or future cash flows associated with the instruments will fluctuate relative to the Canadian dollar due to changes in foreign exchange rates.

Approximately \$2,500 (2014 - \$9,000) of club's cash is denominated in U.S. currency. However, the club primarily transacts in Canadian dollars and so management does not believe the club is exposed to significant currency risk. 
(ii) Interest rate risk

Interest rate risk refers to the risk that the fair value of financial instruments or future cash flows associated with those instruments will fluctuate due to changes in market interest rates. The club's exposure to interest rate risk arises from its interest bearing assets.

The club's cash includes amounts on deposit with Canadian financial institutions that earn interest at market rates. Fluctuations in market rates of interest on cash do not have a significant impact on the club's financial operations.

The club manages the interest rate risk of its investments by the implementation of prudent investment policies. The club's investments in bonds mature at face value on a staggered basis over the next 14 years. The laddered structure of the maturities helps to enhance the average portfolio yield while reducing the

\section{Investments}

Short-term investments are comprised of:

Province of New Brunswick (zero-coupon bond) $-4.30 \%$ yield due December 3, 2015

Equitable Bank (GIC) - 1.45\% due February 18, 2016 Matured in year

Long-term investments are comprised of:

Province of New Brunswick (zero-coupon bond) $-30 \%$ yield due December 3, 2015

Home Trust Company (GIC) - 2.40\% due October 12, 2016

Ontario Hydro (zero-coupon bond) $-4.01 \%$ yield due November 26, 2016

Laurentian Bank (GIC) - 1.65\% due February 21, 2017

Province of Ontario (zero-coupon bond) $-4.07 \%$ yield due December 2, 2017

Province of Ontario (zero-coupon bond) $-2.58 \%$ yield due December 2, 2018

National Bank of Canada (GIC) $-1.86 \%$ due

February 19, 2019

Province of British Columbia (zero-coupon bond) 3.74\% yield due March 5, 2019

Royal Bank of Canada (GIC) - 2.51\% due September 29, 2019

Newfoundland \& Labrador (zero-coupon bond) -

$4.36 \%$ yield due January 7,2020

Home Trust Company (GIC) - 2.15\% due February 18, 2020

Province of British Columbia (zero-coupon bond) -

$3.26 \%$ yield due August 23, 2021

Nova Scotia Power (zero-coupon bond) -

$2.80 \%$ yield due February 26, 2022

Province of Manitoba (zero-coupon bond) $-2.60 \%$ yield due September 5, 2022

Hydro Quebec (zero-coupon bond) $-3.12 \%$ yield due February 15, 2023 sensitivity of the portfolio to the impact of interest rate fluctuations. Effective interest rates to maturity for these securities range from $2.58 \%$ to $4.40 \%$ (2014 $-2.58 \%$ to $4.36 \%)$.

(iii) Other price risk

Other price risk refers to the risk that the fair value of financial instruments or future cash flows associates with the instruments will fluctuate because of changes in market prices (other than those arising from currency risk or interest rate risk), whether those changes are caused by factors specific to the individual instrument or its issuer or factors affecting all similar instruments traded in the market.

The club is not exposed to other price risk.

Changes in risk

There have been no changes in the club's risk exposures from the prior year.

\begin{tabular}{|c|c|c|}
\hline \multicolumn{3}{|c|}{20} \\
\hline & $\begin{array}{l}\text { Yarket } \\
\text { Value }\end{array}$ & $\begin{array}{c}\text { Amortized } \\
\text { Cost }\end{array}$ \\
\hline$\$$ & $\begin{array}{l}60,323 \\
85,756\end{array}$ & $\begin{array}{r}\$ \quad 60,047 \\
85,756\end{array}$ \\
\hline & - & - \\
\hline$\$$ & 146,079 & $\$ 145,803$ \\
\hline
\end{tabular}

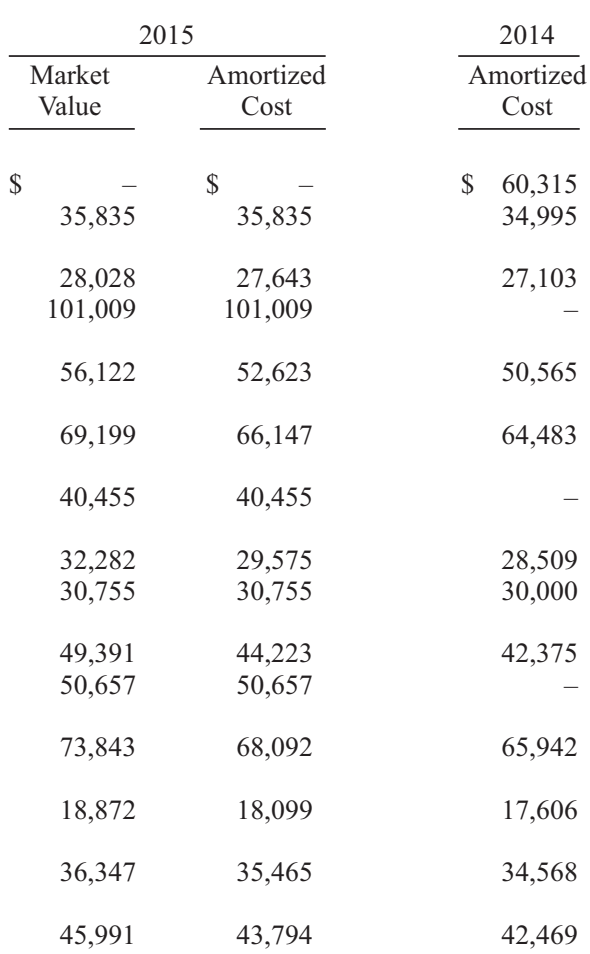

\begin{tabular}{rr}
\multicolumn{2}{c}{2014} \\
$\begin{array}{c}\text { Amortized } \\
\text { Cost }\end{array}$ \\
\hline$\$ \quad-$ \\
\\
$\quad 70,622$ \\
\hline$\$ \quad 70,622$ \\
\hline
\end{tabular}

8,509

2,375

5,942

7,606

2,469 


\section{Investments (continued)}

Long-term investments are comprised of:

Province of Ontario (zero-coupon bond) $-2.90 \%$ yield due September 8, 2024

TD Bank (zero-coupon bond) $-2.93 \%$ yield due May 26, 2025

Province of Manitoba (zero-coupon bond) $-3.82 \%$ yield due September 5, 2025

Newfoundland \& Labrador (zero-coupon bond) $2.67 \%$ yield due February 27, 2026

Province of Ontario (zero-coupon bond) $-3.07 \%$ yield due June 2, 2026

Province of British Columbia (zero-coupon bond) $2.71 \%$ yield due Dec 18, 2027

Bell Canada (zero-coupon bond) $-4.40 \%$ yield due May 1, 2029

A portion of the club's investments totalling $\$ 37,622$ $(2014-\$ 37,063)$ is restricted for endowment purposes. The club has not segregated and identified any particular investment as being held for endowment purposes. Rather, the club allocates a portion of the total interest generated during the year on all of its investments to the endowment fund based upon the opening endowment fund's balance in comparison to the club's opening net assets.

\section{Capital Assets}

No capital assets have been expensed and included in the statements of operations in either the current or preceding fiscal year.

\section{Commitments}

Life memberships

The club is committed to provide for regular membership benefits to lifetime members. Since it is not practicable to

\begin{tabular}{|c|c|c|}
\hline \multicolumn{2}{|c|}{2015} & 2014 \\
\hline $\begin{array}{c}\text { Market } \\
\text { Value }\end{array}$ & $\begin{array}{c}\text { Amortized } \\
\text { Cost }\end{array}$ & $\begin{array}{c}\text { Amortized } \\
\text { Cost } \\
\end{array}$ \\
\hline 36,922 & 35,894 & - \\
\hline 73,954 & 77,649 & - \\
\hline 56,058 & 50,823 & 48,953 \\
\hline 63,389 & 65,384 & - \\
\hline 38,005 & 36,798 & - \\
\hline 34,897 & 35,736 & - \\
\hline 49,599 & 51,691 & - \\
\hline$\$ 1,021,610$ & $\$ 998,347$ & $\$ 547,883$ \\
\hline
\end{tabular}

determine the total liability associated with providing these benefits for the rest of the lives of these individuals, the annual costs are expensed as incurred. Lifetime memberships are no longer being offered by the club. As of September 30, 2015, there were 48 (2014 - 49) remaining lifetime members.

\section{Fletcher Wildlife Garden}

The club is committed to maintain the Fletcher Wildlife Garden, a 6.5 hectare property on the Central Experimental Farm in Ottawa, Ontario. The costs to maintain the property are approximately 2,000 hours of voluntary human resources per year, plus regular maintenance and cleaning supplies. The fair value of the contributed human resources are not recognized in these financial statements.

\section{Comparative Figures}

Certain comparative figures have been reclassified where necessary to conform to the presentation adopted in the current year. 